\title{
DISCHARGE AFTER ELECTIVE UNCOMPLICATED LAPAROSCOPIC CHOLECYSTECTOMY: CAN THE POSTOPERATIVE STAY BE REDUCED?
}

\author{
Goran Glavčić ${ }^{1}$, Mario Kopljar ${ }^{1,2}$, Mario Zovak $^{1,3,4}$ and Dubravka Mužina-Mišić ${ }^{1}$ \\ ${ }^{1}$ Department of Surgery, Sestre milosrdnice University Hospital Centre, Zagreb, Croatia; \\ ${ }^{2}$ Osijek Faculty of Medicine, Josip Juraj Strossmayer University of Osijek, Osijek, Croatia; \\ ${ }^{3}$ School of Medicine, University of Zagreb, Zagreb, Croatia; ${ }^{4}$ School of Dental Medicine, \\ University of Zagreb, Zagreb, Croatia
}

\begin{abstract}
SUMMARY - The aim of the study was to reevaluate the safety and feasibility of discharge $24 \mathrm{~h}$ after elective uncomplicated laparoscopic cholecystectomy. Since the introduction of laparoscopic cholecystectomy in our hospital, the minimum postoperative stay was considered to be two days based on surgeons' experience. The study included 337 operations performed by 21 surgeons during 2016 in the Sestre milosrdnice University Hospital Centre. Conversion to open technique and cases of acute cholecystitis were excluded, while 15 patients had insufficient postoperative data. The mean length of stay was 2.38 (range 1 to 6 ) postoperative days, median two postoperative days. Serious complications involving suspected drain bile leakage and postoperative hemorrhage occurred in two $(0.59 \%)$ patients, both in the first $24 \mathrm{~h}$ following surgery. One patient required emergency laparotomy on the first postoperative day. Readmission rate was $1.2 \%$. The postoperative minor complication rate was 42 of 337 (12.46\%); these included wound infections, urinary tract infections, symptoms included in postcholecystectomy syndrome, etc. The onset of these complications was mostly after postoperative day 3 . The data obtained suggest that discharge on the first postoperative day after elective uncomplicated laparoscopic cholecystectomy should be considered safe and can be practiced in our hospital.
\end{abstract}

Key words: Cholecystectomy, laparoscopic; Patient discharge; Length of stay; Postoperative complications; Health care costs; Croatia

\section{Introduction}

Since its introduction in 1985, laparoscopic cholecystectomy has rapidly become the method of choice for elective procedures and remains one of the most frequently performed operations in developed world ${ }^{1}$, including Croatia and Sestre milosrdnice University Hospital Centre. The first laparoscopic cholecystectomy in our hospital was performed in 1996. Since the introduction of this method, most surgeons in our hospital have preferred to discharge patients after at

Correspondence to: Goran Glavcici, $M D$, Department of Surgery, Sestre milosrdnice University Hospital Centre, Vinogradska c. 29, HR-10000 Zagreb, Croatia

E-mail: glavcic.goran@gmail.com

Received November 23, 2017, accepted July 17, 2018 least $48 \mathrm{~h}$ based on their experience. Studies suggest that most patients having undergone elective uncomplicated laparoscopic cholecystectomy can be safely discharged after 24 postoperative hours, and in some cases, discharge on the same day can be considered ${ }^{2}$.

Our study was set up to reevaluate the hospitalestablished practice of patient discharge on postoperative day 2. We hypothesized that the length of stay could be reduced to $24 \mathrm{~h}$ in cases of elective uncomplicated laparoscopic cholecystectomy.

\section{Patients and Methods}

We carried out a retrospective review including patients that underwent elective laparoscopic cholecystectomies in Sestre milosrdnice University Hospital 
Centre during the year 2016. A total of 678 cholecystectomies were performed during the year. Cholecystectomies during other procedures (Whipple operation, gastrectomy, etc.), procedures for acute cholecystitis and conversions to open technique were excluded. There were 352 elective laparoscopic cholecystectomies performed during the year, while data on $15 \mathrm{pa}^{-}$ tients were insufficient for analysis of postoperative recovery; thus, 337 patients were ultimately included in the study. Twenty-eight patients had previously undergone endoscopic retrograde cholangiopancreatography (ERCP), and 12 patients had previously suffered a bout of pancreatitis. There were 248 female and 89 male patients, average age 54 years; the oldest patient was aged 87 and the youngest 18 .

Data were collected from discharge letters, operative protocols and ambulatory check-up documentation archived in the hospital patient admission system (Sustav prijema pacijenata) computer application. Radiologic findings were extracted from ISSA computer application.

We analyzed operative findings, drain placement, length of postoperative hospital stay, and incidence of early and late postoperative complications requiring ambulatory treatment or hospital readmission. Ambulatory follow-up documentation was analyzed to monitor patient recovery including wound healing, incidence of postoperative pain and introduction of regular diet.

\section{Results}

In the period from January 1, 2016 to December 31, 2016, a total of 337 patient outcomes were analyzed. We found that in all 337 cases, abdominal drain was placed in the subhepatic space; data on the time of drain removal were insufficient, but most were removed on postoperative day one. Polyposis of the gallbladder was the indication for operative treatment in 15 cases, and only one case was confirmed by histopathologic analysis. In two cases, histopathologic analysis revealed adenocarcinoma of the gallbladder. In 14 cases, another procedure was completed during the operation, including 6 repairs of umbilical hernia, 1 extirpation of a mesenteric cyst, 1 drainage of a liver cyst, 1 extirpation of a benign abdominal wall tumor, 1 bilateral TEP hernia repair, 1 resection of a fistula between the transverse colon and the gallbladder, 1 liver biopsy for suspected neoplasm, 1 salpingectomy and 1 Nissen fundoplication.

The mean postoperative hospital stay was 2.38 days (SD 0.77 , median two days), ranging from 1 to 6 days. Some patients that required longer stay included four people with hospital urinary infections, four people that needed adjustment of anticoagulant therapy, and ten people prescribed oral antibiotic therapy after discharge (mostly empirical therapy for patients that had previously undergone ERCP). Patients operated on Thursdays and Fridays were often discharged on Mondays (i.e. on postoperative day 3 or 4 ) because of administrative reasons.

Concerning complications, two patients had significant bile or hemorrhagic drain secretion, both during the first 24 postoperative hours. The patient that had fever and $200 \mathrm{~mL}$ of suspected bile drain secretion did not require reoperation. Follow-up abdominal ultrasound showed no intra-abdominal fluid collection, the secretion stopped, and fever subsided after empirical antibiotic therapy. The patient that required reoperation fainted and suffered head injury during his first postoperative night; computed tomography (CT) of the brain showed no signs of brain damage or skull fracture. On the first operative morning, there was significant blood discharge noted in the abdominal drain; abdominal ultrasound and CT scan confirmed intraabdominal bleeding. Emergency laparotomy was performed and an aberrant hepatic artery was ligated. Further postoperative recovery was uneventful and the patient was hospitalized for six postoperative days.

Fourteen (4.15\%) patients sought emergency surgical care after discharge, four (1.18\%) of these required hospital readmission. The reasons for the emergency room visit were pain, fever and/or vomiting. Ten patients were released home, eight had normal ultrasound and laboratory findings. Two patients started antibiotic therapy, one for urinary tract infection and wound infection each. The four patients that were readmitted to the hospital suffered different complications, as follows: one patient was readmitted on postoperative day 12 for subhepatic hematoma; the symptoms regressed after intravenous antibiotic therapy and no surgical procedure was required; one patient was admitted on postoperative day 9 for suspected choledocholithiasis; further tests showed no signs of gallstones in the common bile duct; and two patients were readmitted for signs of pancreatitis (on postop- 
Table 1. Minor complication incidence

\begin{tabular}{|l|l|l|}
\hline Complication & $\begin{array}{l}\text { Number of } \\
\text { cases (N=42) }\end{array}$ & $\begin{array}{l}\text { Percentage } \\
(\%)\end{array}$ \\
\hline Minor abdominal pain & 14 & 4.15 \\
Wound swelling/hematoma & 7 & 2.07 \\
Wound infection & 7 & 2.07 \\
Urinary tract infection & 5 & 1.48 \\
Occasional vomiting & 3 & 0.89 \\
Heartburn & 3 & 0.89 \\
Obstipation & 3 & 0.89 \\
\hline
\end{tabular}

erative day 9 and 14) but no further surgical intervention was needed.

There were 283 (83.97\%) patients that had an entirely uneventful postoperative recovery with no symptoms and complications recorded during follow-ups. Of the remaining 54 patients, 42 suffered objective minor complications (Table 1) and 12 had subjective symptoms, which could not be verified with clinical, laboratory or radiologic findings (itching, vertigo). The majority of these complications occurred more than a week after the operation. Most required diet adjustment, symptomatic treatment and/or minor surgical intervention, while some required no intervention at all.

\section{Discussion}

Since the introduction of the laparoscopic method and its near-universal acceptance, there have been attempts to exploit the method advantages. These benefits include shorter hospital stay, less postoperative pain, faster return to full activity, and reduced costs ${ }^{3-7}$. Early studies concluded that it could be safely performed as an outpatient procedure in high-volume academic centers ${ }^{8}$.

Based on the combined experience of the Department of Surgery, Sestre milosrdnice University Hospital Centre, our current practice includes minimum two postoperative days after laparoscopic cholecystectomy. While some surgeons often discharge their patients after 24 hours, most tend to respect the Department policy of 48 postoperative hours or more. This practice has proved to be safe, and some feel there is no need for change.

With more than 350 elective laparoscopic cholecystectomies per year, our hospital can be considered a high-volume center concerning this procedure. All of our abdominal surgeons perform the operation and are considered proficient in it.

The study we undertook showed an extremely low rate of hospital readmission after discharge (1.18\%), and readmission occurred on postoperative day 11 on average (ranging from 9 to 14 days). As shown earlier, only one patient required another laparotomy because of bleeding. The one patient that had a suspected bile leak showed no further drain secretion and no evidence for abdominal collection. These were the most dangerous early postoperative complications, and both showed symptoms in the first 24 postoperative hours.

Other minor complications $(n=42,12.46 \%)$ were noted during later follow-ups and could be treated efficiently in outpatient setting; some may have been caused by factors during hospitalization including at least one case of nosocomial urinary infection.

Since no serious complications occurred during the second 24 postoperative hours, it can be assumed that the majority of patients included in the study could have been safely discharged on postoperative day one. This would have allowed a higher turnover of patients on surgical wards, thus allowing more procedures and more vacant hospital beds. Since our hospital serves a large proportion of the Zagreb and Central Croatia population, including emergency services, a higher patient turnover is certainly desirable (if safely achievable). It could also help reduce the time on hospital waiting lists, which are a chronic issue in the Croatian healthcare system.

The cost reduction that could be achieved by decreasing the average hospital stay by one day is hard to access. The current health policy in Croatia computes hospital stay costs by the procedures undertaken, not by days of treatment or materials used. The only estimate that can be used is the sum awarded after outpatient laparoscopic cholecystectomy performed in certain Croatian hospitals. This sum amounts to approximately 6700 Croatian HRK (about $900 €$ ). These circumstances make it nearly impossible to calculate the potential financial benefit of earlier discharge.

\section{References}

1. McSherry CK. Cholecystectomy: the gold standard. Am J Surg. 1989;158(3):174-8.

2. Psaila J, Agrawal S, Fountain U, Whitfield T, Murgatroyd B, Dunsire MF, et al. Day-surgery laparoscopic cholecystectomy: factors influencing same-day discharge. World J Surg. 2008; 32(1):76-81. DOI: $10.1007 / \mathrm{s} 00268-007-9225-\mathrm{x}$ 
3. Barkun JS, Sampalls JS, Fried G, et al. Randomised controlled trial of laparoscopic versus mini cholecystectomy. Lancet. 1992;340(8828):1116-9.

DOI: 10.1016/0140-6736(92)93148-G

4. Bass EB, Pitt HA, Lillemoe KD. Cost-effectiveness of laparoscopic cholecystectomy versus open cholecystectomy. Am J Surg. 1993;165(4):466-71.

5. McMahon AJ, Russell IT, Ramsay G, Sunderland G, Baxter JN, Anderson JR, et al. Laparoscopic and mini laparotomy cholecystectomy: a randomized trial comparing postoperative pain and pulmonary function. Surgery. 1994;115(5):533-9.
6. Trondsen E, Reiertsen O, Andersen OK, Kjaersgaard P. Laparoscopic and open cholecystectomy. A prospective, randomized study. Eur J Surg. 1993;159(4):217-21.

7. Berggren U, Gordh T, Grama D, Haglund U, Rastad J, Arvidsson D. Laparoscopic versus open cholecystectomy: hospitalization, sick leave, analgesia and trauma responses. Br J Surg. 1994;81(9):1362-5.

8. Lillemoe KD, Lin JW, Talamini MA, Yeo CJ, Snyder DS, Parker SD. Laparoscopic cholecystectomy as a "true" outpatient procedure: initial experience in 130 consecutive patients.J Gastrointest Surg. 1999;3(1):44-9.

Sažetak

\title{
OTPUST IZ BOLNICE NAKON ELEKTIVNE NEKOMPLICIRANE LAPAROSKOPSKE KOLECISTEKTOMIJE: MOŽE LI SE SKRATITI POSLIJEOPERACIJSKI BORAVAK U BOLNICI?
}

\author{
G. Glavčic, M. Kopljar, M. Zovak i D. Mužina-Mišić
}

Cilj studije bio je reevaluirati sigurnost i izvodljivost otpusta bolesnika u prva 24 sata nakon elektivnih laparoskopskih kolecistektomija. Od uvođenja laparoskopske metode u našoj ustanovi, prema iskustvu kirurga smatralo se kako je minimalni poslijeoperacijski boravak 2 dana. Studija je obuhvatila 337 operacija koje je proveo 21 kirurg u 2016. godini u KBC "Sestre milosrdnice". Isključeni su slučajevi konverzije u otvorene operacije kao i slučajevi akutnog kolecistitisa. Kod 15 bolesnika nije bilo dovoljno podataka o poslijeoperacijskom tijeku. Prosjek poslijeoperacijskog boravka bio je 2,38 (1 do 6) dana, medijan je bio 2 dana. Ozbiljne komplikacije u vidu suspektnog curenja žuči i poslijeoperacijskog krvarenja pojavile su se kod dvoje $(0,59 \%)$ bolesnika; oba slučaja dogodila su se unutar 24 sata od operacije. Kod jednog bolesnika indicirana je hitna reoperacija prvog poslijeoperacijskog dana. Stopa ponovnog prijma u bolnicu bila je 1,2\%. Manje poslijeoperacijske komplikacije dogodile su se kod 42 (12,46\% operiranih) bolesnika; ove komplikacije uključivale su infekcije rane, uroinfekcije, simptome postkolecistektomijskog sindroma itd. Ove komplikacije događale su se uglavnom nakon 3. poslijeoperacijskog dana. Prikupljeni podaci ukazuju na to da se otpust prvog poslijeoperacijskog dana nakon elektivne nekomplicirane laparoskopske kolecistektomije može smatrati sigurnim i provoditi tu praksu u našoj ustanovi.

Ključne riječi: Kolecistektomija, laparoskopska; Bolesnik, otpust; Duljina boravka; Poslijeoperacijske komplikacije; Zdravstvena zaštita, troškovi; Hrvatska 